\title{
Learning methodology in surgical training
}

\author{
Metodologia de ensino no treinamento de habilidades cirúrgicas
}

Cristina P. Camargo ${ }^{1}$, Rolf Gemperli², José Otavio Costa Auler Junior ${ }^{3}$

Camargo CP, Gemperli R, Auler Junior JOC. Learning methodology in surgical training / Metodologia de ensino no treinamento de habilidades cirúrgicas. Rev Med (São Paulo). 2018 jan.-fev.;97(1):7-11.

\begin{abstract}
This manuscript aimed to review the literature data related to the surgical training program. This review showed some of the requirements to perform effective surgical training were direct supervision, predetermined repetitions according to surgical skill complexity, valid simulator models, number of students per model. This manuscript discussed how the surgical program could achieve competence using a critical thinking framework, integrated curriculum based on the rationale behind simulation training program.
\end{abstract}

Keywords: General surgery/education; Education/methods; Training/methods; Simulation training/methods.

\section{INTRODUCTION}

Hor many decades, the Halstedian paradigm was
used in surgical learning: "see one, do one, teach one." However, since 2003, the learning method had changed due to the new medical curriculum demands ${ }^{1}$.

We list below some of these demands ${ }^{2,3}$ :

- New guidelines -better quality of patient assistance;

- Patient safety demands;
RESUMO: Esse manuscrito tem como objetivo revisar dados da literatura relacionados ao treinamento cirúrgico para alunos de graduação me medicina. Essa revisão demostrou que alguns pré requesitos são necessários para se realizar treinamento cirúrgico de maneira eficaz: supervisão direta, repetições pré-determinadas de acordo com a complexidade da atividade a ser ensinada, modelos de simuladores válidos, número de alunos por modelo. Esse manuscrito também discutiu como o programa cirúrgico pode levar a competência pelo desenvolvimento do pensamento crítico e pela integração curricular baseado no racional da utilização de um programa de treinamento por simuladores.

Descritores: Cirurgia geral/educação; Educação/métodos; Capacitação/métodos; Treinamento por simulação/métodos.

1. Disciplina de Cirurgia Plastica, Faculdade de Medicina FMUSP, Universidade de São Paulo, Sao Paulo, SP, BR. Division of Plastic Surgery, Department of Surgery, School of Medicine, Laboratory of Microsurgery and Plastic Surgery (LIM-04), University of São Paulo, SP, Brazil. https:// orcid.org/0000-0002-3134-0003

2. Disciplina de Cirurgia Plastica, Faculdade de Medicina FMUSP, Universidade de Sao Paulo, Sao Paulo, SP, BR. Full Professor and Head, Division of Plastic Surgery, Department of Surgery, School of Medicine USP, São Paulo, SP, Brazil. Email: rolf.gemperli@fm.usp.br; https://orcid.org/00000001-9913-6079.

3. Faculdade de Medicina FMUSP, Universidade de Sao Paulo, Sao Paulo, SP, BR. Dean of FMUSP, Full Professor and Head, Division of Anesthesiology, School of Medicine, Laboratory of Anesthesiology (LIM-08), University of São Paulo, SP, Brazil. Email: jose.otavio@fm.usp.br; https://orcid. org/0000-0002-3919-1743

Correspondence: Cristina Camargo. Av. Brigadeiro Luis Antonio, 4161. CEP: 01401-001 SãoPaulo, SP, Brazil. Email: consultoriodracristina@gmail.com 
a certain number of procedures repetitions to build a stepwise learning curve. The number of repetitions depends on the nature and complexity of this surgical skill. For example, to teach a simple task, glowing, it is necessary three to five repetitions; but to train a more complex surgical skill, E.g., central intravenous access it is required a higher number of repetitions (10-15 times) $)^{1,3}$.
Because of the significant knowledge load, the clinical rotation must be rescheduled to adapt the great knowledge volume in a shorter period. Therefore, the achievement of competence requires a more integrative curriculum, and a student-centered learning process.

In summary, we need an adequate education background to improve the learning process.

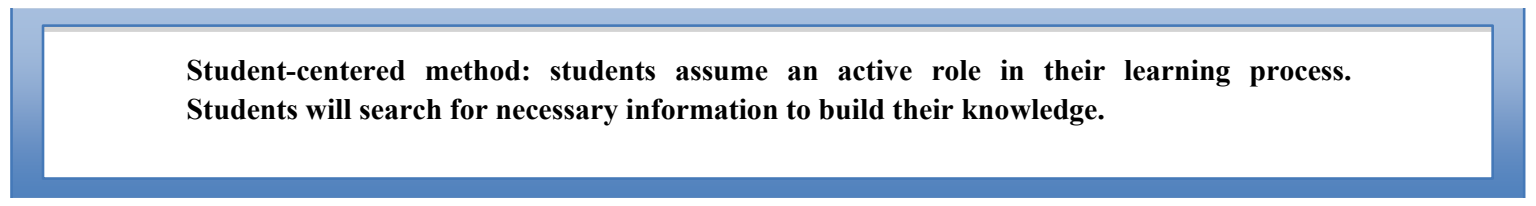

Competence: successful performance of a particular ability.

To achieve this purpose, the students need to pass through some learning phases. According to Fitts and
Posner's theory, the learner has to go through three steps ${ }^{4}$ (Figure 1).

\section{Cognitive}

Theoretical knowledge

How to do it

Read books, articles

\section{Associative}

Central Nervous System integration with peripheral muscle

The students need to think how to do a specific activity

\section{Autonom ous}

There is no need to think about the procedure

The acticity is spontaneous, fluid moviment

Figure 1 - Fitts and Posner's three steps theory. In the first phase (cognitive), the student learns by books, articles, and the task. In the second phase (associative), the knowledge is transmitted to motor activities. Finally, in the third step (autonomous), the student is familiar with the motor activity and, there is no need to think about how to perform the activity

\section{Educational Background}

New methods of training are available and changing over the time.

According to The Association of Surgeons in Training (ASIT) and, the Joint Committee on Surgical Training (JCST), the new educational technologies must be integrated to promote multi-surgical specialties. For example, knots and suture training can be practiced in the majority of surgical fields ${ }^{5,6}$.

The surgical clerkship needs to consider the following aspects to organize practical surgical training:

- Simulator model;

- Number of repetitions;

- Classroom's basic schedule;

- Student's and staff's feedback.

\section{Simulator model}

Despite several simulators alternatives (Table 1), we need to consider some aspects.

Regarding the use of animal models in learning training, most medical schools abandoned this modality. From 171 American Medical Schools, only three schools use animal models for learning purposes ${ }^{7}$. More than $95 \%$ of Canadian and British schools eliminated animals as an educational learning model ${ }^{8}$.

Despite ethical issues, we have to consider the level of fidelity. In basic training (E.g., knots and suture), a lowfidelity model (board tying device) shows similar results when compared to a high-fidelity model (humans replicas devices, computer simulators). See Table 1.

Table 1. Surgical model for training ${ }^{9}$

\begin{tabular}{|l|l|l|}
\hline Simulator model & Description & Technical aspects \\
\hline Low fidelity & Knot tying boards & Low cost, the student can use it at home \\
\hline High fidelity model & Humans replicas (body or some specific region) & Expensive, commercially available, maintenance cost \\
\hline Animal model & Live animals (rats, mice, swine) & Expensive, ethical issues \\
\hline Computer simulator & Interactive programs, virtual & High cost, purchase maintenance \\
\hline
\end{tabular}




\section{Simulation ${ }^{10}$ _"A situation in which a particular set of conditions is created artificially in order to study or experience something that could exist in reality".}

The challenge of the non-animal simulation is the creation of a real environment condition to mimic clinical situations.

In the last instance, surgical training aims to encode all the skills and information to produce a long-term memory. In this context, a systematic review analyzed 27 randomized clinical trials (RCTs) about the impact of the simulation-based curriculum in the operation room (real life). These RCTs showed a benefit in surgical performance due to simulation ${ }^{11}$.

\section{Number of repetitions}

The ideal number of repetitions to achieve competence depends on the skill complexity.

We reviewed the data available in the literature to support our educational program. See Table 2.

However, these numbers of repetitions only will be valid with direct supervision (teacher, monitors).

Table 2. Basic surgical abilities and number of repetition to achieve competence

\begin{tabular}{|c|c|}
\hline Ability & Number of repetitions \\
\hline $\begin{array}{l}\text { Apparatus, instruments, hand hygiene, surgical hand washing, garment and gloves placement, surgical } \\
\text { site preparation, antisepsis }{ }^{12-14}\end{array}$ & 3 to 5 \\
\hline Nasogastric tubes ${ }^{14}$ & 3 to 5 \\
\hline Vesical catheter ${ }^{14,16,17}$ & 3 to 5 \\
\hline Peripheral venous and arterial access ${ }^{14}$ & 3 to 5 \\
\hline Central venous access ${ }^{14-5}$ & More than 10 \\
\hline Airway access ${ }^{14,18}$ & 3 to 5 \\
\hline \multirow{2}{*}{ Knots/ Suture ${ }^{19,20}$} & Knots $60-80$ \\
\hline & Suture 5 to 10 \\
\hline Drains and wound care $\mathrm{c}^{14,21}$ & 5 to 10 \\
\hline Local anesthesia/wound debridement ${ }^{14,22}$ & 5 to 10 \\
\hline
\end{tabular}

\section{Classroom's basic schedule}

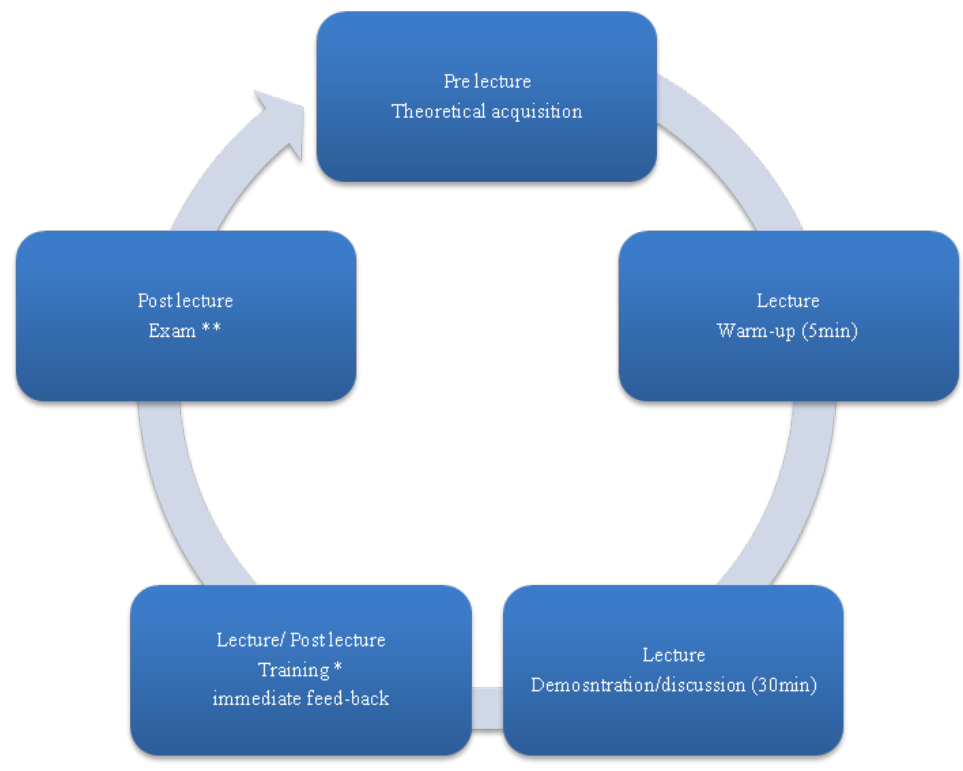

* The training period depends on the ability

** The exam can be conducted as a pre-test and a post-test

Figure 2. Classroom structure for learning process 
This structure aims to improve the effectiveness of the learning process. We must highlight some aspects:

- The student needs to study before the lecture;

- A warm-up period (first 5 minutes) is necessary to connect the previous learning to the training;

- During the lecture, some fast questions and interaction is mandatory to increase knowledge acquisition;

- Training depends on the previous student experience, handiness;

- Small groups (5-10 students) organization with one or two monitors;

- Immediate feedback for technical adjustments (Figure 2).

\section{Student's and staff's feedback}

Constant and immediate feedback must be given to improve training effectiveness. The teacher's feedback aims to correct an error in real-time performance and, to discuss some steps of the procedure ${ }^{23}$.

On the other hand, student's feedbacks are interesting. In the student's comments, the clerkship can evaluate the learning process during the course (formative grading). This information is fundamental for learning effectiveness improvement. The second aspect is that the faculty can receive data for fine adjustments in the learning process.

\section{CONCLUSION}

In conclusion, this manuscript reviewed validated methods to train basic abilities in surgery (Apparatus, instruments, hand hygiene, surgical hand washing, garment and gloves placement, surgical site preparation, antisepsis, venous access, arterial access, knots, and suture).

\section{Formative assessment- the goal is to monitoring student's performance during learning process.}

This assessment allows an immediate intervention to improve learning.

Summative exam- the goal is to evaluate the final performance.

\section{REFERENCES}

1. Yiasemidou M, Glassman D, Tomlinson J, Song D, Gough MJ. Perceptions about the present and future of surgical simulation: a national study of mixed qualitative and quantitative methodology. J Surg Educ. 2016;74(1):108-16. doi: 10.1016/j.jsurg.2016.07.011.

2. Stefanidis D. Optimal acquisition and assessment of proficiency on simulators in surgery. Surg Clin North Am. 2010;90(3):475-89. doi: 10.1016/j.suc.2010.02.010.

3. Reznick RK, MacRae H. Teaching surgical skills-changes in the wind. N Engl J Med. 2006;355:2664-9. doi: 10.1056/ NEJMra054785.

4. Fitts PM, Posner MI. Human performance. Belmont, CA: Brooks/Cole; 1967.

5. Agha RA, Papanikitas A, Baum M, Benjamin IS. The teaching of surgery in the undergraduate curriculum. Part II e Importance and recommendations for change. Int J Surg. 2005;3:151-7. https://doi.org/10.1016/j.ijsu.2005.03.016.

6. Scally C, Minter RM. Medical school training for the surgeon. Surg Clin North Am. 2016; 96:1-13. doi: 10.1016/j. suc.2015.08.007.

7. Physicians Committee for Responsible Medicine. Replacing animal laboratories: what you can do; Medical students [cited 2017 Sept 7]. Available from: http://www.pcrm.org/research/ edtraining/meded/replacing-animal-laboratories-what-youcan-do.

8. Solanki D. Unnecessary and cruel use of animals for medical undergraduate training in India. J Pharmacol Pharmacother. 2010;1(1):59. doi:10.4103/0976-500X.64537.

9. Acton RD. The evolving role of simulation in teaching surgery in undergraduate medical education. Surg Clin North Am. 2015;95:739-50. doi: 10.1016/j.suc.2015.04.001.

10. Tavakol M, Mohagheghi MA, Dennick R. Assessing the skills of surgical residents using simulation. J Surg Educ. 2008;65(2):77-83. doi: 10.1016/j.jsurg.2007.11.003.

11. Dawe SR, Pena GN, Windsor JA, Broeders JA, Cregan PC, Hewett PJ, Maddern GJ. Systematic review of skills transfer after surgical simulation-based training. Br J Surg. 2014;101(9):1036-76.doi: 10.1002/bjs.9482.

12. World Health Organization (WHO). World Alliance for Safer Health Care. WHO guidelines on hand hygiene in health care. First global patient safety challenge clean care is sager care [cited 2017 Aug 20]. Available from: http://apps.who.int/iris/ bitstream/10665/44102/1/9789241597906_eng.pdf.

13. Fichtner A, Haupt E, Karwath T, Wullenk K, Pohlmann C, Jatzwauk L. A single standardized practical training for surgical scrubbing according to EN1500: effect quantification, value of the standardized method and comparison with clinical reference groups. GMS Z Med Ausbild. 2013;30(2):Doc24. doi: 10.3205/zma000867.

14. Suwanrath C, Samphao S, Prechawai C, Singha P. Confidence in essential procedural skills of Thai medical graduates. Int J Clin Skills. 2016;10(1):6-10. Available from: http://www. ijocs.org/clinical-journal/confidence-in-essential-procedural- 
skills-of-thai-medical-graduates.html.

15. Moore CL. Ultrasound first, second, and last for vascular access. J Ultrasound Med. 2014;33:1135-42. doi: 10.7863/ ultra.33.7.1135.

16. Queen's University. School of Medicine. Urinary catheterization. Steps in male catheterization [cited 2017 Nov $6^{\text {th }}$. Available from: https://meds.queensu.ca/central/ assets/modules/ts-urinary-catheterization/steps_in_male_ catheterization.html.

17. Cardiff University. Prifysgol Caerdydd. Clinical Skills and Simulation Team. Female catheterization [cited 2017 Nov. $6^{\text {th }}$. Available from: https://learningcentral.cf.ac.uk/ bbcswebdav/institution/Medic/Undergraduate/Female $\% 20$ Catheterisation/Female\%20Catheterisation.pdf.

18. Stringer KR, Bajenov S, Yentis SM. Training in airway management. Anaesthesia. 2002;57:967-83. doi: 10.1046/j.1365-2044.2002.02830.x.

19. Pender C, Kiselov V, Yu Q, Mooney J, Greiffenstein P, Paige JT. All for knots: evaluating the effectiveness of a proficiency-driven, simulation-based knot tying and suturing curriculum for medical students during their third-year surgery clerkship. Am J Surg. 2016;0002-9610(16):30453-6. doi: 10.1016/j.amjsurg.2016.06.028.

20. Goova MT, Hollett LA, Tesfay ST, Gala RJ, Puzziferri N, Kehdy FJ, Scott DJ. Implementation, construct validity, and benefit of a proficiency-based knot-tying and suturing curriculum. J Surg Educ. 2008;65(4):309-15. doi: 10.1016/j. jsurg.2008.04.004.

21. The Royal Children's Hospital Melbourne. Clinical guidelines (nursing) [cited 2017 Sept 10]. Available from: http://www.rch.org.au/rchcpg/hospital_clinical_guideline_ index/Wound_care/.

22. Udani AD, Kim TE, Howard SK, Mariano ER. Simulation in teaching regional anesthesia: current perspectives. Local Reg Anesth. 2015;8:33-43. doi: 10.2147/LRA.S68223

23. Rafiq A, Tamariz F, Boanca C, Lavrentyev V, Merrell RC. Objective assessment of training surgical skills using simulated tissue interface with real-time feedback. J Surg Educ. 2008;65(4):270-4. doi: 10.1016/j.jsurg.2008.05.012.

Recebido em: 13.11 .17

Aceito em: 